\title{
Yield of cherry tomatoes as a function of water salinity and irrigation frequency
}

\author{
Alexandre N. Santos ${ }^{1}$, Ênio F. de F. e Silva ${ }^{2}$, Gerônimo F. da Silva ${ }^{2}$, \\ Janice M. C. Barnabé ${ }^{2}$, Mario M. Rolim² \& Daniel da C. Dantas ${ }^{2}$ \\ ${ }^{1}$ Instituto Federal de Educação, Ciência e Tecnologia de Pernambuco/Campus Barreiros. Barreiros, PE. E-mail: alexandrens14@yahoo.com.br \\ (Corresponding author) \\ ${ }^{2}$ Universidade Federal Rural de Pernambuco/Departamento de Engenharia Agrícola. Recife, PE. E-mail: enio.silva@deagri.ufrpe.br; agrogefe@yahoo.com.br; \\ janice_coelho@yahoo.com.br; rolim@deagri.ufrpe.br; d1cdantas@hotmail.com
}

\section{Key words:}

Lycopersicon esculentum Mill hydropony

semiarid

\begin{abstract}
A B S T R A C T
The use of brackish water in agriculture can cause salinization of soils and reduce plant yield. This problem can be minimized by hydroponic cultivation, which improves plant development. The aim of this study was to evaluate the yield of cherry tomatoes grown in hydroponic system with substrate under salinity levels of the nutrient solution (NS), exposure time to salinity and irrigation frequency. The experiment was conducted in a greenhouse, in a randomized complete block design, in a $6 \times 2 \times 2$ factorial scheme with five replicates: six salinity levels of NS prepared with brackish water $(3.01 ; 4.51 ; 5.94 ; 7.34$; 8.71 and $10.40 \mathrm{dS} \mathrm{m}^{-1}$ ); two exposure times to NS (60 and 105 days) and two irrigation frequencies (one irrigation per day and irrigation every two days). Yield and production components of cherry tomatoes cv. 'Rita' were evaluated. NS salinity affected plant yield, reducing fruit production, which was more significant when plants were subjected to a longer time of exposure to salinity. There was no difference between NS applications on fruit production, when these applications were performed once a day or once every two days.
\end{abstract}

\section{Palavras-chave:}

Lycopersicon esculentum Mill hidroponia semiárido

\section{Rendimento do tomate cereja em função da salinidade da água e do turno de rega}

\begin{abstract}
R E S U M O
O uso de água salobra na agricultura pode promover a salinização dos solos reduzindo a produção das plantas. Este problema é passível de ser minimizado nos cultivos hidropônicos visto que promove, às plantas, melhores condições de desenvolvimento. Objetivou-se, neste trabalho, avaliar o rendimento do tomate cereja cultivado em hidroponia com substrato em função da salinidade da solução nutritiva preparada com água salobra (SN), do tempo de exposição à salinidade e do turno de rega. O experimento foi conduzido em casa de vegetação em blocos casualizados em esquema fatorial $6 \times 2 \times 2$ com cinco repetições, sendo: seis níveis de salinidade da SN preparada com água salobra $(3,01 ; 4,51 ; 5,94 ; 7,34$; 8,71 e 10,40 $\mathrm{dS} \mathrm{m}^{-1}$ ); dois tempos de exposição à SN (60 e 105 dias) e dois turnos de rega (uma irrigação por dia e uma irrigação a cada dois dias). Foram avaliados a produção e os componentes de produção do tomate cereja cultivar 'Rita'. A salinidade da SN afetou o rendimento das plantas reduzindo a produção de frutos sendo esta redução mais acentuada quando as plantas foram submetidas a um tempo maior de exposição à salinidade. Não houve diferença entre as aplicações de SN sobre a produção de frutos quando essas aplicações foram realizadas uma vez por dia ou uma vez a cada dois dias.
\end{abstract}




\section{INTRODUCTION}

In many occasions, brackish water is the only water source available for human use and agricultural activities in the semiarid regions of Northeast Brazil (Costa et al., 2006). Using water with this quality may pose risks to the environment, promoting soil salinization due to the accumulation of salts in the profile, thus reducing plant production (Netto et al., 2007; Garcia et al., 2008).

Environmental risks and production losses can be minimized with the use of crop techniques that promote improvements on plant development. In this sense, hydropony has been indicated as a cultivation alternative suitable to regions where only brackish water is available (Santos et al., 2010; Cosme et al., 2011; Gomes et al., 2011).

In the cultivation in soils, the decrease in osmotic potential promoted by the use of water with high salt concentrations, combined with the matric potential, is the main factor interfering with water absorption by plants. In hydropony, these effects are reduced due to the great availability of water and nutrients guaranteed by the high frequency of application of the nutrient solution (NS) and by the small influence of matric potential (Santos et al., 2010; Soares et al., 2010; Barreto et al., 2012).

The use of crops more tolerant to salts can increase the efficiency of hydroponic crops with the use of brackish water, making viable the use of waters with higher salinity levels and satisfactory fruit production. Thus, the tomato crop emerges as an important alternative (Campos et al., 2007; Oliveira et al., 2007).

Gomes et al. (2011), studying the cultivation of cherry tomato in hydroponic system using powder of coconut fibre as a support for the roots and applying NS with different proportions of saline wastewater derived from brackish water desalinization, concluded that, in terms of yield, the threshold salinity for cherry tomato (cv. 'Samambaia') in hydropony is $3.5 \mathrm{dS} \mathrm{m}^{-1}$.

Another factor that can be employed as a strategy for the use of brackish water in hydroponic crops, when water of better quality is also available, is the period of exposure of plants to salinity, preserving one of the crop stages.

In this context, Amor et al. (2001) and Cosme et al. (2011), cultivating hydroponic tomato using NS prepared with brackish water, applied in different crop development stages, observed that plant yield was higher when salinized NS was applied later and that there was higher damage to production when the solution was applied from the initial stage of the cycle on.

Irrigation frequency is also an important factor in agricultural crops, because it has direct effects on water availability in the cultivation medium and can directly influence crop production (Marouelli \& Silva, 2005; Monte et al., 2009).

In hydropony, NS applications are performed in high frequency and, when associated with the use of substrate, NS can be applied in longer intervals, due to the capacity of the substrate to store NS (Rodrigues, 2002), allowing greater autonomy of the system and economy in electricity (Andriolo et al., 2004).
On the other hand, a longer interval between irrigations can subject plants to water deficit and, when combined with salinity conditions, it can intensify the negative effects of this stress on plants, with direct impact on production (Zanella et al., 2008; Monte et al., 2009; Cosme et al., 2011).

Considering that the management of NS prepared with brackish water interferes with yield of cherry tomatoes cultivated in hydropony with substrate, this study aimed to evaluate crop yield as a function of NS salinity, exposure time to salinity and irrigation frequency.

\section{Material ANd Methods}

The experiment was carried out in a greenhouse at the Department of Agricultural Engineering of the Federal Rural University of Pernambuco - UFRPE, from May 13 to September 10,2013 , using a hydroponic system in pots with powder of coconut fibre for the cultivation of cherry tomato, cv. 'Rita'.

Each pot had a volume of $8.0 \mathrm{~L}$ and received a 2 -cm-thick layer of crushed stone, which was covered with geotextile and $2.0 \mathrm{~kg}$ of powder of coconut fibre $(<4 \mathrm{~mm})$. For this amount of substrate, the maximum water retention capacity was $3.02 \mathrm{~L}$.

A drip irrigation system was installed for the application of NS to plants. The system consisted of six pairs of 200-L tanks, attached to a centrifugal pump equipped with a set of taps originating the lateral lines used to distribute the NS. Each lateral line corresponded to one treatment and had five pressure-compensating drippers with nominal flow rate of $4.0 \mathrm{~L} \mathrm{~h}^{-1}$. Irrigations were performed to increase the water retention in the substrate until its maximum.

Cherry tomato seedlings were transplanted 30 days after sowing, leaving one plant per pot. The spacing between plants was $0.50 \mathrm{~m}$ and between lines was $1.0 \mathrm{~m}$. Plants were initially maintained in acclimation regime and the NS was prepared only with water from the local supply system until 15 days after transplanting (DAT); after this period, the treatments started and NS was prepared with brackish water.

For the preparation of brackish water, salts were added to the water from the local supply system in order to simulate the chemical composition of the groundwater collected in the 'Poço do Boi' community, located in the municipality of Ibimirim, semiarid region of Pernambuco.

The collected water had electrical conductivity of $1.7 \mathrm{dS} \mathrm{m}^{-1}$, due to the presence and concentrations of the following ions: $\mathrm{K}=2.7 \mathrm{mg} \mathrm{L}^{-1} ; \mathrm{Ca}=74.2 \mathrm{mg} \mathrm{L}^{-1} ; \mathrm{Mg}=71.9 \mathrm{mg} \mathrm{L}^{-1} ; \mathrm{Na}=179.8$ $\mathrm{mg} \mathrm{L}^{-1} ; \mathrm{SO}_{4}=133.4 \mathrm{mg} \mathrm{L}^{-1} ; \mathrm{Cl}=383.7 \mathrm{mg} \mathrm{L}^{-1} ; \mathrm{CO}_{3}=52.9$ and $\mathrm{HCO}_{3}=361.2 \mathrm{mg} \mathrm{L}^{-1}$ (Santos et al., 2010).

The amounts of salts necessary to obtain water with electrical conductivity levels of 1.5, 3.0, 4.5, 6.0 and $7.5 \mathrm{dS} \mathrm{m}^{-1}$ were calculated, maintaining the proportions of concentrations of the ions. After salinization and before NS preparation, the $\mathrm{pH}$ of these waters was adjusted to 5.0, in order to avoid probable precipitation of salts during the preparation of the solution.

NS formulation in the present study followed the recommendations of Furlani et al. (1999) for the cultivation of hydroponic tomato in different phenological stages, according to Table 1. All the treatments received the same formulation 
Table 1. Composition of the nutrient solution indicated by Furlani et al. (1999) for tomato crop in different vegetative stages of the cycle

\begin{tabular}{|c|c|c|c|c|c|c|c|c|c|c|c|c|}
\hline \multirow{3}{*}{$\begin{array}{l}\text { Crop } \\
\text { stage }\end{array}$} & \multicolumn{7}{|c|}{ Macronutrients } & \multicolumn{5}{|c|}{ Micronutrients } \\
\hline & $\mathrm{NO}_{3}^{-}$ & $\mathrm{NH}_{4}{ }^{+}$ & $\mathbf{P}$ & $\mathrm{K}$ & $\mathrm{Ca}$ & $\mathrm{Mg}$ & $S$ & B & $\mathrm{Cu}$ & $\mathrm{Fe}$ & $\mathrm{Mn}$ & Mo \\
\hline & \multicolumn{12}{|c|}{$\left(\mathrm{mg} \mathrm{L}^{-1}\right)$} \\
\hline Stage A & 135 & 35 & 52 & 314 & 152 & 40 & 70 & 0.5 & 0.05 & 2.4 & 0.75 & 0.06 \\
\hline Stage B & 150 & 37 & 52 & 326 & 190 & 40 & 70 & 0.5 & 0.05 & 2.4 & 0.75 & 0.06 \\
\hline Stage C & 164 & 38 & 52 & 409 & 209 & 40 & 70 & 0.5 & 0.05 & 2.4 & 0.75 & 0.06 \\
\hline
\end{tabular}

Stage A - From sowing to 30 days after seedling transplantation; Stage B - From 30 to 60 days after seedling transplantation; and Stage C - From 60 after seedling transplantation until the end of harvest

of nutrients, always applied after preparation and adjustment of $\mathrm{pH}$ of the waters.

The effects of brackish water used in hydroponic cultivation of cherry tomato in substrate were analysed based on three variation sources: salinity of nutrient solution prepared with brackish water (ECsol), time of exposure of plants to salinity (TES) and irrigation frequency (IF)

Plants were subjected to six salinity levels in the nutrient solution obtained using brackish water with different salinities (previously mentioned), combined with the salinity from the addition of fertilizers recommended for its formulation. During the experiment, the mean values of electrical conductivity of the NS for the different levels were: 3.01, 4.51, 5.94, 7.34, 8.71 and $10.40 \mathrm{dS} \mathrm{m}^{-1}$.

The solutions prepared with brackish water were applied in two different periods of the crop cycle: from 15 to 120 DAT and from 60 to 120 DAT, subjecting plants to two TES, 105 and 60 days, respectively. Plants were also subjected to two IF: one irrigation per day (IF1) and one irrigation every two days (IF2).

The experiment was set in a randomized complete block design, in a $6 \times 2 \times 2$ factorial (ECsol x TES x IF) with five replicates, totaling 120 experimental plots. The data were subjected to analysis of variance by $\mathrm{F}$ test for the sources of variation and the effects of blocks and interactions.

For the effects on the variables caused by the source of variation "ECsol", regression analysis was performed by adjusting the polynomial models selected after analysis of equation parameters by $\mathrm{F}$ test at 0.05 probability level and by the highest value of the coefficient of determination. As to the effects on the variables caused by the sources of variation "TES" and "IF", the data were analysed by comparison of means using Tukey test at 0.05 probability level (Gomes, 2000).
Cherry tomato yield was evaluated by maintaining six bunches per plant and performing weekly harvest of the fruits from the beginning of the production (58 DAT - $1^{\circ}$ harvest) until 120 DAT (last harvest).

The following variables were determined in each plant: number of flowers (NFL), counting the number of peduncles of the bunches of each plant; total number of fruits (TNF), counting the total number of fruits harvested per plant; number of aborted flowers (NAFL), by the difference between TNF and NFL; total fruit fresh matter per plant (g) (TFFM), by weighing the fruits obtained per plant on a precision scale $(0.01 \mathrm{~g})$; fruit transverse diameter $(\mathrm{mm})$ (FTD), by measuring with a caliper the longest distance of a transverse plane in the fruit; and total fruit dry matter per plant (g) (TFDM), by weighing on a precision scale $(0.01 \mathrm{~g})$ the fruits obtained in each plant after they were dried in a forced-air oven at $70{ }^{\circ} \mathrm{C}$ until constant mass.

\section{Results AND Discussion}

The increase in the salinity levels of the nutrient solution (ECsol) affected total fruit fresh matter (TFFM) and dry matter (TFDM) productions, fruit transversal diameter (FTD), number of flowers (NFL) and the number of aborted flowers (NAFL) of cherry tomatoes plants cultivated in hydropony with coconut fibre; however, it did not affect the total number of fruits per plant (TNF).

Production variables also suffered the effects of time of exposure of plants to salinity (TES), except for the number of aborted flowers per plant (NAFL), in contrast to the irrigation frequency (IF), which affected only this variable (Table 2).

There were no effects of the triple interaction between the studied factors on the production variables, but the double

Table 2. Analysis of variance for the variables total fruit fresh matter (TFFM), total fruit dry matter (TFDM), total number of fruits (TNF), fruit transversal diameter (FTD), number of flowers (NFL) and number of aborted flowers (NAFL) of cherry tomato as a function of the salinity level in the nutrient solution (ECsol), time of exposure to salinity (TES) and irrigation frequency (IF)

\begin{tabular}{|c|c|c|c|c|c|c|c|}
\hline \multirow{2}{*}{$\begin{array}{c}\text { Source } \\
\text { of variation }\end{array}$} & \multirow{2}{*}{ DF } & \multicolumn{6}{|c|}{ Mean square } \\
\hline & & TFFM & TFDM & TNF & FTD & NFL & NAFL \\
\hline Block & 4 & $14448.19^{\text {ns }}$ & 169.70 ** & $92.29^{\text {ns }}$ & $3.27^{\mathrm{ns}}$ & $142.82^{\mathrm{ns}}$ & $109.95^{\mathrm{ns}}$ \\
\hline ECsol & 5 & $193462.68 * *$ & $560.81^{* *}$ & $28.80^{\text {ns }}$ & $24.02^{* *}$ & $765.33^{\star *}$ & $551.95^{\star *}$ \\
\hline TES & 1 & $712375.02 * *$ & $3277.75^{\star *}$ & $2688.53^{* *}$ & $48.22^{\star \star}$ & $2530.01^{* *}$ & $2.41^{\mathrm{ns}}$ \\
\hline IF & 1 & $21741.40^{\mathrm{ns}}$ & $5.33^{\text {ns }}$ & $299.23^{\text {ns }}$ & $5.66^{\text {ns }}$ & $143.01^{\mathrm{ns}}$ & $612.01 *$ \\
\hline ECsol *TES & 5 & $81350.31 * *$ & $395.29 * *$ & $163.33^{\star *}$ & $9.96^{* \star}$ & $1482.41^{* *}$ & $508.51^{* *}$ \\
\hline ECsol *IF & 5 & $2208.22^{\text {ns }}$ & $6.60^{\text {ns }}$ & $45.63^{\text {ns }}$ & $2.58^{\text {ns }}$ & $259.13^{\text {ns }}$ & $170.59^{\mathrm{ns}}$ \\
\hline TES*IF & 1 & $8732.84^{\mathrm{ns}}$ & $30.40^{\text {ns }}$ & $472.03^{\star}$ & $1.21^{\mathrm{ns}}$ & $1.88^{\text {ns }}$ & $533.41^{\star}$ \\
\hline ECsol *TES*IF & 5 & $12924.14^{\mathrm{ns}}$ & $94.67^{\mathrm{ns}}$ & $145.73^{\text {ns }}$ & $1.58^{\text {ns }}$ & $205.68^{\text {ns }}$ & $120.07^{\mathrm{ns}}$ \\
\hline Error & 92 & 6503.75 & 47.12 & 90.31 & 2.16 & 190.66 & 98.08 \\
\hline CV $(\%)$ & & 11,59 & 11.91 & 13.15 & 5.76 & 12.38 & 25.23 \\
\hline
\end{tabular}

**Significant at 0.01 probability level; *Significant at 0.05 probability; ns Not significant 
interactions between these factors affected cherry tomato yield. The interaction of ECsol $x$ TES promoted effects on all the studied variables. The interaction of ECsol $\mathrm{x}$ IF did not cause effects on the production variables, while the interaction of TES $x$ IF affected TNF and NAFL (Table 2).

The follow-up analysis of the interactions revealed that TFFM production of cherry tomato decreased linearly with the increase in NS salinity level (ECsol) and this decreased was less pronounced as a function of TES. These reductions were $1.45 \%$ per $\mathrm{dS} \mathrm{m} \mathrm{m}^{-1}\left(\mathrm{y}=12.416^{*} \mathrm{X}+855.20^{* *}-\mathrm{R}^{2} 0.459\right)$ for plants subjected to NS prepared with brackish water from 60 to 120 DAT (TES $=60$ days) and $5.66 \%$ per $\mathrm{dS} \mathrm{m}^{-1}$ when plants were exposed to salinity from 15 to 120 DAT (TES = 105 days) (Figure 1A).

Likewise, there was a decrease in TFDM of $4.37 \%$ per unit increase in NS salinity $\left(\mathrm{dS} \mathrm{m}^{-1}\right)$, for plants subjected to TES $=105$ days. However, for a TES $=60$ days, the obtained data for this variable did not fit to linear or quadratic models (Figure 1B).

According to Taiz \& Zeiger (2009), salinity can cause problems of osmotic nature and toxicity, limiting the absorption of water and nutrients, causing the accumulation of specific ions or nutritional disorders in the plants. This fact directly reflects in plant metabolism, development and production.

Other researchers, studying hydroponic tomato cultivation, also observed decrease in production $(5.2,5.3,7.7$ and $6.7 \%$ per $\mathrm{dS} \mathrm{m}^{-1}$ ) as a function of the increase in nutrient solution salinity (Amor et al., 2001; Magán et al., 2008; Cosme et al., 2011; Gomes et al., 2011).

Salinity also influenced flower emergence in cherry tomatoes, reducing NFL by $3.51 \%$ per $\mathrm{dS} \mathrm{m}^{-1}$ (Figure $1 \mathrm{C}$ ). On the other hand, plants responded to the increase in salinity with a reduction in NAFL, which was equal to $5.44 \%$ per $\mathrm{dS}$ $\mathrm{m}^{-1}$ (Figure 1D).
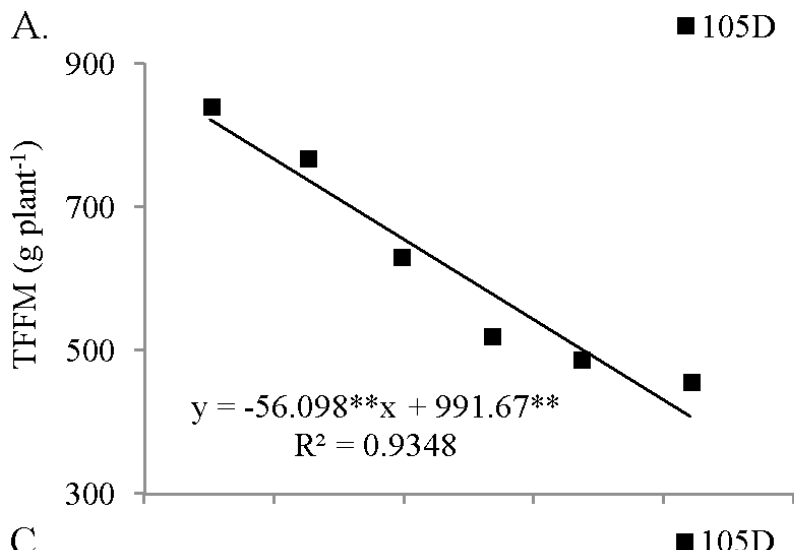

C.

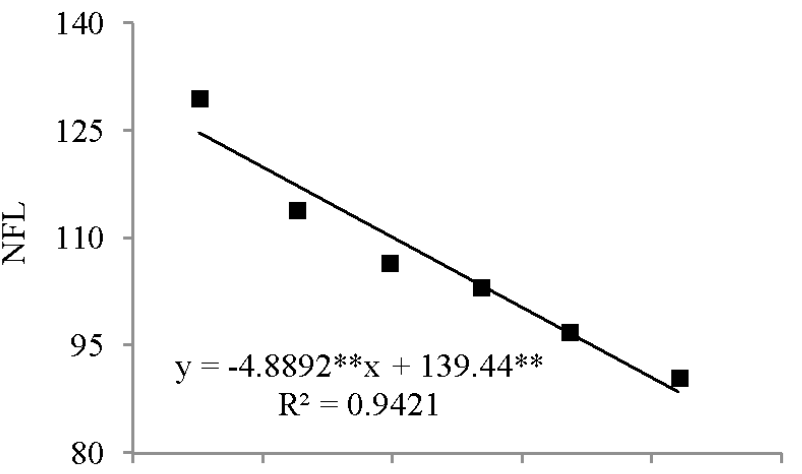

E.

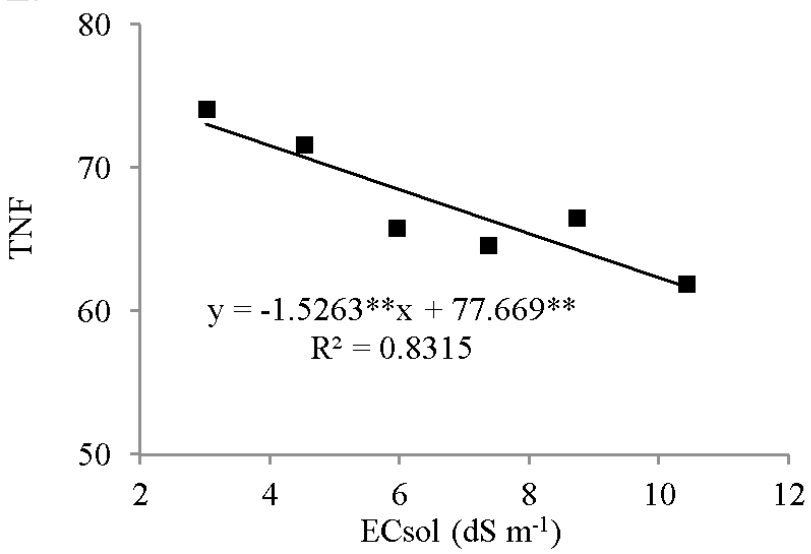

B.
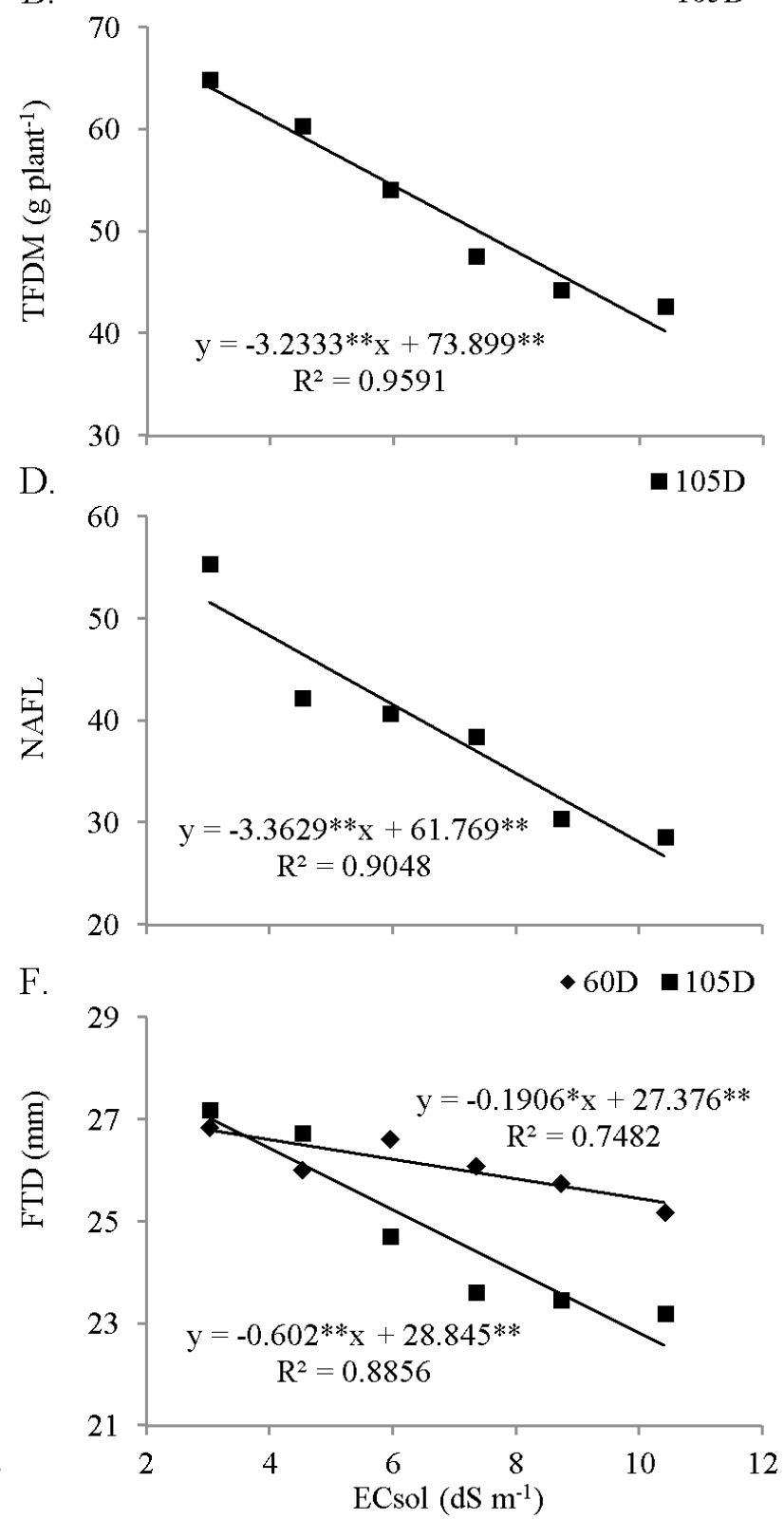

Figure 1. Regression analysis for the effect of nutrient solution salinity (ECsol) inside the factor time of exposure to salinity for the variables total fruit fresh matter (TFFM), total fruit dry matter (TFDM), number of flowers per plant (NFL), number of aborted flowers per plant (NAFL), total number of fruits (TNF) and fruit transversal diameter (FTD) 
Thus, plants affected by salinity showed a less pronounced reduction in TNF, $1.96 \%$ per $\mathrm{dS}^{-1}$. This trend was observed in plants subjected to TES $=105$ days, while plants exposed to salinity for 60 days did not suffer the effects of salinity, with respect to the previously mentioned variable (Figure $1 \mathrm{E}$ ).

Another adaptation strategy of plants to saline stress was the decrease in fruit transversal diameter (FTD) (Figure 1F). This reduction was equal to $0.70 \%$ per $\mathrm{dS} \mathrm{m}^{-1}$ when plants were subjected to TES $=60$ days and $2.09 \%$ per $\mathrm{dS} \mathrm{m}^{-1}$ for TES $=105$ days.

The differences between the means of the production variables, as a function of TES occurred mainly at the highest levels of NS salinity (Table 3). From the ECsol of $5.94 \mathrm{dS} \mathrm{m}^{-1}$ on, the time during which plants were subjected to this solution influenced TFFM production at each salinity level until the highest one $\left(10.40 \mathrm{dS} \mathrm{m}^{-1}\right)$.

Plants subjected to TES $=60$ days showed higher fruit yield inside the salinity levels, compared with plants under TES $=105$ days, and similar results occurred for the variables TNF and FTD. There were also differences between the means of the variable TFDM inside the salinity levels, but these differences occurred from the ECsol of $4.51 \mathrm{dS} \mathrm{m}^{-1}$ to $10.40 \mathrm{dS} \mathrm{m}^{-1}$. As to NFL and NAFL, the differences between means occurred randomly inside the salinity levels. For NFL, there were differences at the levels of 3.01, 5.94, 8.71 and $10.40 \mathrm{dS} \mathrm{m}^{-1}$ and, for NAFL, the differences occurred at the levels of 3.01 and $10.40 \mathrm{dS} \mathrm{m}^{-1}$.

The best production response of cherry tomato plants exposed to salinity for the shortest period (60 days) may also have been influenced by the management strategy adopted for NS application.

The fact that the nutrient solution prepared with brackish water of the treatment with TES of 60 days was applied only

Table 3. Comparison of means for the effect of time of exposure to salinity (TES) inside the levels of nutrient solution salinity (ECsol) for the variables total fruit fresh matter (TFFM), total fruit dry matter (TFDM), total number of fruits (TNF), fruit transverse diameter (FTD), number of flowers (NFL) and number of aborted flowers (NAFL)

\begin{tabular}{|c|c|c|c|c|c|c|c|}
\hline \multirow{2}{*}{$\begin{array}{l}\text { ECsol } \\
\text { (dS m-1) }\end{array}$} & \multirow{2}{*}{$\begin{array}{l}\text { TES } \\
\text { (day) }\end{array}$} & TFFM & TFDM & \multirow{2}{*}{ TNF } & \multirow{2}{*}{$\begin{array}{c}\text { FTD } \\
(\mathrm{mm})\end{array}$} & \multirow{2}{*}{ NFL } & \multirow{2}{*}{ NAFL } \\
\hline & & \multicolumn{2}{|c|}{$\left(\right.$ g plant $\left.^{-1}\right)$} & & & & \\
\hline \multirow{2}{*}{3.01} & 60 & $793.08 \mathrm{a}$ & $60.44 \mathrm{a}$ & $71 \mathrm{a}$ & $26.9 \mathrm{a}$ & $110 \mathrm{~b}$ & $38 \mathrm{~b}$ \\
\hline & 105 & $841.98 \mathrm{a}$ & $64.95 \mathrm{a}$ & $74 \mathrm{a}$ & $27.2 \mathrm{a}$ & $130 \mathrm{a}$ & $56 a$ \\
\hline LSD & & 94.38 & 8.20 & 13.52 & 1.47 & 18.21 & 11.89 \\
\hline \multirow{2}{*}{4.51} & 60 & $816.34 \mathrm{a}$ & $66.54 \mathrm{a}$ & $76 \mathrm{a}$ & $26.0 \mathrm{a}$ & $113 \mathrm{a}$ & $37 \mathrm{a}$ \\
\hline & 105 & $769.05 a$ & $60.41 \mathrm{a}$ & $72 \mathrm{a}$ & $26.7 \mathrm{a}$ & $114 \mathrm{a}$ & $42 \mathrm{a}$ \\
\hline LSD & & 77.77 & 6.54 & 7.36 & 1.16 & 11.86 & 6.54 \\
\hline \multirow{2}{*}{5.94} & 60 & $837.35 \mathrm{a}$ & $67.84 \mathrm{a}$ & $81 \mathrm{a}$ & $26.7 \mathrm{a}$ & $127 \mathrm{a}$ & $46 a$ \\
\hline & 105 & $632.55 \mathrm{~b}$ & $54.20 \mathrm{~b}$ & $66 \mathrm{~b}$ & $24.7 b$ & $107 \mathrm{~b}$ & $41 \mathrm{a}$ \\
\hline LSD & & 78.39 & 8.14 & 7.31 & 1.30 & 11.69 & 9.23 \\
\hline \multirow{2}{*}{7.34} & 60 & $713.48 \mathrm{a}$ & $57.63 \mathrm{a}$ & $78 \mathrm{a}$ & $26.1 \mathrm{a}$ & $114 \mathrm{a}$ & $36 \mathrm{a}$ \\
\hline & 105 & $520.85 b$ & $47.68 \mathrm{~b}$ & $65 \mathrm{~b}$ & $23.6 \mathrm{~b}$ & $103 \mathrm{a}$ & $39 a$ \\
\hline LSD & & 78.38 & 6.17 & 9.47 & 1.29 & 9.96 & 10.66 \\
\hline \multirow{2}{*}{8.71} & 60 & $739.67 \mathrm{a}$ & $61.50 \mathrm{a}$ & $76 \mathrm{a}$ & $25.8 \mathrm{a}$ & $114 \mathrm{a}$ & $38 \mathrm{a}$ \\
\hline & 105 & $488.59 \mathrm{~b}$ & $44.33 \mathrm{~b}$ & $67 \mathrm{~b}$ & $23.5 \mathrm{~b}$ & $97 \mathrm{~b}$ & $31 \mathrm{a}$ \\
\hline LSD & & 89.20 & 7.39 & 8.45 & 1.39 & 10.29 & 9.00 \\
\hline \multirow{2}{*}{10.40} & 60 & $735.78 \mathrm{a}$ & $63.11 \mathrm{a}$ & $80 a$ & $25.2 \mathrm{a}$ & $118 \mathrm{a}$ & $38 a$ \\
\hline & 105 & $458.10 \mathrm{~b}$ & $42.79 \mathrm{~b}$ & $62 \mathrm{~b}$ & $23.2 \mathrm{~b}$ & $91 \mathrm{~b}$ & $29 \mathrm{~b}$ \\
\hline LSD & & 43.39 & 3.69 & 9.36 & 0.96 & 13.64 & 7.38 \\
\hline
\end{tabular}

LSD - Least significant difference; Means followed by the same letters in the columns do not differ by Tukey test at 0.05 probability level from 60 to 120 DAT allowed better plant development in the vegetative growth stage; thus, plants showed higher yield when subjected to saline stress, in comparison to plants subjected to salinity from 15 to 120 DAT.

The alternation between fresh water and brackish water in plant cultivation can be used when there is not enough water of good quality to meet crop requirements along the entire cycle; in this case, higher-quality water is used to preserve the most susceptible stage from the effects of salts and thus minimize the damages caused by salinity on the production.

Similar results were obtained by Amor et al. (2001) and Cosme et al. (2011), studying the response of hydroponic tomato subjected to nutrient solution with different levels of salinity applied in different periods of the crop cycle. These authors also observed that cherry tomato plants suffered lower production losses when nutrient solution salinity was applied later in relation to the beginning of the cycle.

According to Maas (1993), tomato production as a function of TES is influenced by many factors, such as cultivar, phenological stage, composition of the saline environment, stress intensity and duration, edaphoclimatic conditions and irrigation management.

The follow-up analysis of the interaction between TES and IF revealed that inside the highest TES (105 days), the irrigation frequency with one irrigation every two days (IF2) reduced NAFL by $20.45 \%$ and increased TNF by $9.86 \%$, in comparison to the IF with one irrigation per day (IF1). For plants subjected to TES $=60$ days, irrigation frequency did not promote effect on these variables (Table 4 ).

This result indicates the possibility to use a longer interval between the applications of the nutrient solution for plants subjected to TES $=60$ days. This was only possible due to the capacity of the powder of coconut fibre to store nutrient solution (3.02 $\mathrm{L}_{\text {pot }}^{-1}$ ), which can promote economy of electricity in this cultivation system.

The highest TES (105 days) promoted a reduction of $17.95 \%$ in the variable TNF for the IF1, compared with plants subjected to the lowest TES (60 days), while this difference was $6.58 \%$ in the IF2. The result for TNF was influenced by the lower reduction in NAFL of plants subjected to the highest TES of IF2, in relation to IF1 (Table 4).

Table 4. Follow-up analysis of the interaction between the factors irrigation frequency (IF) and time of exposure to salinity (TES) for the variables total number of fruits (TNF) and number of aborted flowers (NAFL)

\begin{tabular}{cccccccc}
\hline \multirow{2}{*}{ IF } & \multicolumn{3}{c}{ TNF } & & \multicolumn{3}{c}{ NAFL } \\
\cline { 2 - 4 } \cline { 5 - 7 } & TES & TES & LSD & TES & TES & LSD \\
IF1 & $\mathbf{1 0 5}$ days & $\mathbf{6 0}$ days & & & $\mathbf{1 0 5}$ days & $\mathbf{6 0}$ days & \\
IF2 & $71 \mathrm{Ab}$ & $78 \mathrm{Aa}$ & 4.8 & & $44 \mathrm{Aa}$ & $39 \mathrm{Aa}$ & 5.8 \\
LSD & 5.0 & 5.3 & & & 5.9 & 6.4 & \\
\hline
\end{tabular}

Means followed by the same letters, uppercase in the columns and lowercase in the rows, do not differ by Tukey test at 0.05 probability level; IF1 - One irrigation per day; IF2 - One irrigation every two days; LSD - Least significant difference

\section{Conclusions}

1. The increase in the salinity of the nutrient solution prepared with brackish water reduced the yield of cherry 
tomato, cv. 'Rita', but this reduction is less intense when plants are exposed to salinity for a shorter time.

2. Nutrient solution prepared with brackish water, applied from 60 days after transplantation on, promotes lower yield losses in cherry tomato.

3. Under the conditions of the present study, the application of nutrient solution in hydroponic cultivation with substrate, performed every two days, does not affect the yield of cherry tomato, cv. 'Rita'.

\section{Literature Cited}

Amor, F. M.; Martinez, V.; Cerdá, A. Salt tolerance of tomato plants as affected by stage of plant development. HortScience, v.36, p.1260-1263, 2001.

Andriolo, J. L.; Ross, T. D.; Witter, M. Crescimento, desenvolvimento e produtividade do tomateiro cultivado em substrato com três concentrações de nitrogênio na solução nutritiva. Ciência Rural, v.34, p.1451-1457, 2004. http://dx.doi.org/10.1590/S010384782004000500019

Barreto, C. V. G.; Testezlaf, R.; Salvador C. A. Dinâmica do potencial matricial em substratos de pinus e coco sob ação da capilaridade. Horticultura Brasileira, v.30, p.26-31, 2012. http://dx.doi. org/10.1590/S0102-05362012000100005

Campos, C. A. B.; Fernandes, P. D.; Gheyi, H. R.; Blanco, F. F. Tomato growth and dry matter partitioning as a function of the irrigation water quality. Revista Ciência Agronômica, v.38, p.239-246, 2007.

Cosme, C. R.; Dias, N. da S.; Oliveira, A. M. de; Oliveira, E. M. M.; Sousa Neto, O. N. de. Produção de tomate hidropônico utilizando rejeito da dessalinização na solução nutritiva aplicados em diferentes épocas. Revista Brasileira de Engenharia Agrícola e Ambiental, v.15, p.499-504, 2011.

Costa, A. M. B.; Melo, J. G.; Silva, F. M. Aspectos da salinização das águas do aquífero cristalino no Estado do Rio Grande do Norte, Nordeste do Brasil. Revista Águas Subterrâneas, v.20, p.67-82, 2006.

Furlani, P. R.; Silveira, L. C. P.; Bolonhezi, D.; Faquin, V. Cultivo hidropônico de plantas. 1.ed. Campinas: IAC, 1999. 52p.

Garcia, G. O.; Martins Filho, S.; Reis, E. F.; Moraes, W. B.; Nazário, A. A. Alterações químicas de dois solos irrigados com água salina. Revista Ciência Agronômica, v.39, p.7-18, 2008.

Gomes, F. P. Curso de estatística experimental. 14.ed. Piracicaba: Degaspari, 2000. 477p.

Gomes, J. W. S.; Dias, N. da S.; Oliveira, A. M.; Blanco, F. F.; Sousa Neto, O. N. de. Crescimento e produção de tomate cereja em sistema hidropônico com rejeito de dessalinização. Revista Ciência Agronômica, v.42, p.850-856, 2011. http://dx.doi.org/10.1590/ S1806-66902011000400005
Maas, E. V. Testing stages for salinity tolerance. In: Maranville, J. W.; Baiigar, B. V.; Duncan, R. R.; Yohe, J. M. (ed.). Workshop on adaptation of plants to soil stresses. Lincoln: University of Nebraska, 1993. p.234-247.

Magán, J. J.; Gallardo, M.; Thompson, R. B.; Lorenzo, P. Effects of salinity on fruit yield and quality of tomato grown in soil-less culture in greenhouses in Mediterranean climatic conditions. Agricultural Water Management, v.95, p.1041-1055, 2008. http:// dx.doi.org/10.1016/j.agwat.2008.03.011

Marouelli, W. A.; Silva, W. L. C. Frequência de irrigação por gotejamento durante o estádio vegetativo do tomateiro para processamento industrial. Pesquisa Agropecuária Brasileira, v.40, p.661-666, 2005. http://dx.doi.org/10.1590/S0100204X2005000700006

Monte, J. A.; Pacheco, A. S.; Carvalho, D. F.; Pimentel, C. Influência do turno de rega no crescimento e produção do tomateiro no verão em Seropédica. Horticultura Brasileira, v.27, p.222-227, 2009. http://dx.doi.org/10.1590/S0102-05362009000200018

Netto, A. de O. A.; Gomes, C. C. S.; Lins, C. C. V.; Barros, A. C.; Campeche, L. F. de S. M.; Blanco, F. F. Características químicas e salino-sodicidade dos solos do Perímetro Irrigado Califórnia, SE, Brasil. Ciência Rural, v.37, p.1640-1645, 2007. http://dx.doi. org/10.1590/S0103-84782007000600021

Oliveira, B. C.; Cardoso, M. A. A.; Oliveira, J. C.; Oliveira, F. A.; Cavalcante, L. F. Características produtivas do tomateiro submetido a diferentes níveis de sais, na água de irrigação. Revista Brasileira de Engenharia Agrícola e Ambiental, v.11, p.11-16, 2007. http://dx.doi.org/10.1590/S1415-43662007000100002

Rodrigues, L. R. F. Técnicas de cultivo hidropônico e de controle ambiental no manejo de pragas, doenças e nutrição vegetal em ambiente protegido. 1.ed. Jaboticabal: FUNEP, 2002. 762p.

Santos, A. N.; Soares, T. M.; Silva, E. F. F.; Silva, D. J. R.; Montenegro, A. A. A. Cultivo hidropônico de alface com água salobra subterrânea e rejeito da dessalinização em Ibimirim, PE. Revista Brasileira de Engenharia Agrícola e Ambiental, v.14, p.961-969, 2010. http:// dx.doi.org/10.1590/S1415-43662010000900008

Soares, T. M.; Duarte, S. N.; Silva, E. F. F.; Jorge, C. A. Combinação de águas doce e salobra para produção de alface hidropônica. Revista Brasileira de Engenharia Agrícola e Ambiental, v.14, p.705-714, 2010. http://dx.doi.org/10.1590/S1415-43662010000700004

Taiz, L.; Zeiger, E. Fisiologia vegetal. 4.ed. Porto Alegre: Artmed, 2009. 848p.

Zanella, F.; Lima, A. L. S.; Silva Júnior, F. F.; Maciel, S. P. A. Crescimento de alface hidropônica sob diferentes intervalos de irrigação. Ciência e Agrotecnologia, v.32, p.366-370, 2008. http:// dx.doi.org/10.1590/S1413-70542008000200003 